Article

\title{
Anodic Protection Assessment Using Alumina-Forming Alloys in Chloride Molten Salt for CSP Plants
}

\author{
Angel G. Fernández ${ }^{\mathbb{D}}$ and Luisa F. Cabeza * $\mathbb{D}$ \\ GREiA Research Group, Universitat de Lleida, Pere de Cabrera s/n, 25001 Lleida, Spain; \\ angel.fernandez@diei.udl.cat \\ * Correspondence: lcabeza@diei.udl.cat
}

Received: 8 December 2019; Accepted: 29 January 2020; Published: 4 February 2020

check for updates

\begin{abstract}
The generation of a natural protective coating in alumina-forming alloys was analyzed using a ternary chloride molten salt as a thermal energy storage material for concentrated solar power (CSP) technology. The formation of the protective layer was monitored using electrochemical impedance spectroscopy (EIS). A protective layer model for the OCT alloy and a localized corrosion model for the OCI and OC4 alloys were obtained after $5 \mathrm{~h}$ of immersion. The corrosion rates calculated using the linear polarization technique (LPR), were 8.03, 21.55, and $7.61 \mathrm{~mm} /$ year for OC4, OCI, and OCT alloys, respectively. These results were confirmed by scanning electron microscopy and $X$-ray diffraction. Our analysis showed that $\mathrm{MgAl}_{2} \mathrm{O}_{4}$ was the main protective coating generated by the alumina-forming alloys.
\end{abstract}

Keywords: concentrated solar power; thermal energy storage; corrosion mitigation; chloride molten salt; alumina-forming alloys; anodic protection

\section{Introduction}

In the last years, an opportunity to obtain higher power generation efficiencies has been identified by integrating the supercritical $\mathrm{CO}_{2}\left(\mathrm{sCO}_{2}\right)$ Brayton power cycle. To achieve this integration, storage temperatures in concentrated solar power (CSP) plants must be high (up $550{ }^{\circ} \mathrm{C}$ ). In order to raise the storage temperature, a molten salt with suitable chemistry is needed. Some of the main challenges of using high-temperature molten salts are that they must be compatible with the commercial alloys that will be in contact with the storage materials and that alloy requirements and costs should be balanced [1].

Due to their low cost and high decomposition temperature, molten chlorides are considered to be good candidates. The high operation temperatures require the study of corrosion mitigation strategies to reduce the corrosion rate of the containment materials to around $20 \mu \mathrm{m} / \mathrm{year}$, since their life cycle needs to be at least of 30 years [2-4]. One of the corrosion mitigation strategies is thermal purification development in chloride salt before the start of the corrosion process. This approach, previously analyzed by Fernandez and Cabeza [5], achieved a corrosion rate reduction of around $68 \%$.

On the other hand, the use of coatings as protective barriers on the surface of steel is a second possibility, although it could increase the system's cost. For example, the use of alumina-forming alloys has been studied, since alumina scales (generated on the surface of steel) were reported to be more protective than chromia scales, which usually form on conventional stainless steel [6].

The generation of anodic protection layers in chloride molten salts has been developed by different authors. Indacochea et al. [7] analyzed the corrosion resistance of several ferrous alloys and tantalum specimens in lithium chloride salt, obtaining higher corrosion resistance under reducing conditions. 
A second approach to achieve corrosion mitigation consists in the addition of a sacrificial anode to the molten salt. Garcia-Diaz [8] and Ding [9] reported a reduction of the corrosion rates when a metal of $\mathrm{Mg}$ in a chloride molten salt was used as cathodic protection. Specifically, the addition of $1.15 \mathrm{wt} . \%$ of $\mathrm{Mg}$ reduced the corrosion rate of Haynes 230 at $850{ }^{\circ} \mathrm{C}$ by 35 times, reaching a value of less than $15 \mu \mathrm{m} /$ year, when compared to the baseline rate measured without the addition of $\mathrm{Mg}$. A key consequence of this effect was the deposition of $\mathrm{MgO}$ on the cathode, which led to the passivation of this electrode, causing a significant reduction of the electrolysis current [9]. These strategies for corrosion mitigation were also summarized in a recent review by Ding et al. [10].

In summary, the aim of this paper was to analyze the corrosion resistance of different alumina-forming alloys in contact with a ternary chloride molten salt, proposed as an anodic protection strategy.

\section{Anodic Protection in Chloride Molten Salts}

Anodic protection is a corrosion mitigation strategy that controls the corrosion rate of the surface to be protected by making it the anode of an electrochemical cell. The initial reaction of the anode is usually accompanied by surface passivation which hinders the reaction and, hence, corrosion. Before applying these anodic protection strategies, some purification treatments in chloride molten salts, aiming to reduce corrosive impurities, have been suggested [4]. One of the most studied mixtures consisted of $\mathrm{MgCl}_{2}-\mathrm{NaCl}-\mathrm{KCl}\left(60-20-20 \mathrm{~mol} \%\right.$ ), which has a melting point of $\sim 400{ }^{\circ} \mathrm{C}$ and a thermal stability up to $800^{\circ} \mathrm{C}$. Water molecules in $\mathrm{MgCl}_{2}$ (hexahydrate) need to be removed, since $\mathrm{MgOHCl}$ was identified by some authors [11-14] as the main corrosive impurity that is formed through the following reaction at $\sim 167^{\circ} \mathrm{C}$ [15]:

$$
\mathrm{MgCl}_{2} \cdot 2 \mathrm{H}_{2} \mathrm{O} \rightarrow \mathrm{MgOHCl}+\mathrm{HCl}+\mathrm{H}_{2} \mathrm{O}
$$

The dehydration of the monohydrate occurs at $\sim 235^{\circ} \mathrm{C}$ and also produces $\mathrm{MgOHCl}$ :

$$
\mathrm{MgCl}_{2} \cdot \mathrm{H}_{2} \mathrm{O} \rightarrow \mathrm{MgOHCl}+\mathrm{HCl}
$$

Ding et al. reported a thermal decomposition of $\mathrm{MgOHCl}$ between $\sim 415{ }^{\circ} \mathrm{C}$ and $\sim 555{ }^{\circ} \mathrm{C}$ [16] producing $\mathrm{MgO}$ and $\mathrm{HCl}$ :

$$
\mathrm{MgOHCl} \rightarrow \mathrm{MgO}+\mathrm{HCl}
$$

The strategy of using coatings as anodic protection has been proposed recently, especially for specific components inside the CSP plant, i.e., turbine blades [17]. Coatings could be a suitable option in order to decrease corrosive attacks by molten salts and to reduce the cost of container materials used in storage tanks and pipelines. Some coatings tested in the literature are composed of MCrAlX (M: $\mathrm{Ni}$, and/or Co; X: Y, Hf, Si, and/or Ta) [17] and form an adherent alumina layer on the alloy surface providing high-temperature corrosion resistance in chloride molten salt.

The resistance of aluminum coatings as slurries or alumina-forming alloys has been widely tested, resulting acceptable in harsh environments. Audigie et al. [18] evaluated the corrosion resistance of an $\mathrm{Al}$ coating slurry immersed in $60 \% \mathrm{NaNO}_{3}+40 \% \mathrm{KNO}_{3}$ molten salt at $580{ }^{\circ} \mathrm{C}$, obtaining a better resistance compared with that of uncoated steel (P92).

These results have raised a significant interest in alumina-forming alloys (AFAs) as storage container material with good corrosion-resistance. AFAs, consisting of alumina protective layers, have been proposed as substitutes of chromia layers, which has been normally formed in commercial stainless steel $[19,20]$.

Gomez-Vidal evaluated AFAs exposed to molten $\mathrm{MgCl}_{2}-64.41 \mathrm{wt} . \% \mathrm{KCl}$ at $700{ }^{\circ} \mathrm{C}$ in a flowing Ar atmosphere [2]. In this research, Inconel 702 (IN702), Haynes 224 (HR224), and Kanthal APMT (APMT) were pre-oxidized at different temperatures, for different dwelling times, and in different atmospheres to produce the protective layers. Electrochemical tests and conventional long-term 
tests based on weight changes were both used to down-select the best-performing alloy and surface pre-oxidation conditions.

Linear sweep voltammetry (LSV) measurement and sample characterization showed that the IN702 alloy presented the best corrosion-resistant properties due to the formation of a stable $\alpha-\mathrm{Al}_{2} \mathrm{O}_{3}$ coating. It is important to highlight that this alloy was pre-oxidized in zero air (ZA) at $1050{ }^{\circ} \mathrm{C}$ for $4 \mathrm{~h}$. On the other hand, another pre-oxidation method was carried out with this alloy, using Ar instead ZA, forming $\alpha-\left(\mathrm{Al}_{0.9} \mathrm{Cr}_{0.1}\right)_{2} \mathrm{O}_{3}$. This coating showed reduced protective properties due to the presence of the less stable $\mathrm{Cr}$. Since this pre-oxidation process would increase the material's cost, in this research, alumina-forming alloys are proposed as a protective coating in the corrosive environment of the operation conditions.

\section{Materials and Methods}

The molten salt tested was a eutectic mixture composed of $20.4 \mathrm{wt} . \% \mathrm{KCl}+55.1 \mathrm{wt} . \%$ $\mathrm{MgCl}_{2}+24.5 \mathrm{wt} . \% \mathrm{NaCl}$ (Sigma Aldrich, St. Louis, MO, USA, with $99 \%$ purity), at $720{ }^{\circ} \mathrm{C}$ under inert atmosphere $\left(\mathrm{N}_{2}\right)$.

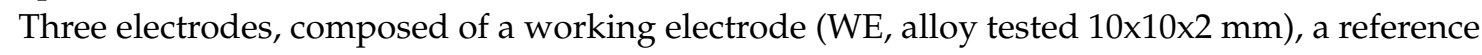
electrode (RE, Pt wire), and a counter electrode (CE, Pt mesh), were used. The lectrodes were immersed in the molten salt, acting as an electrolyte, and the open circuit potential (OCP) was measured using a potentiostat (Gamry 1010E, Gamry, Warminster, PA, USA). The experimental apparatus is shown in Figure 1.

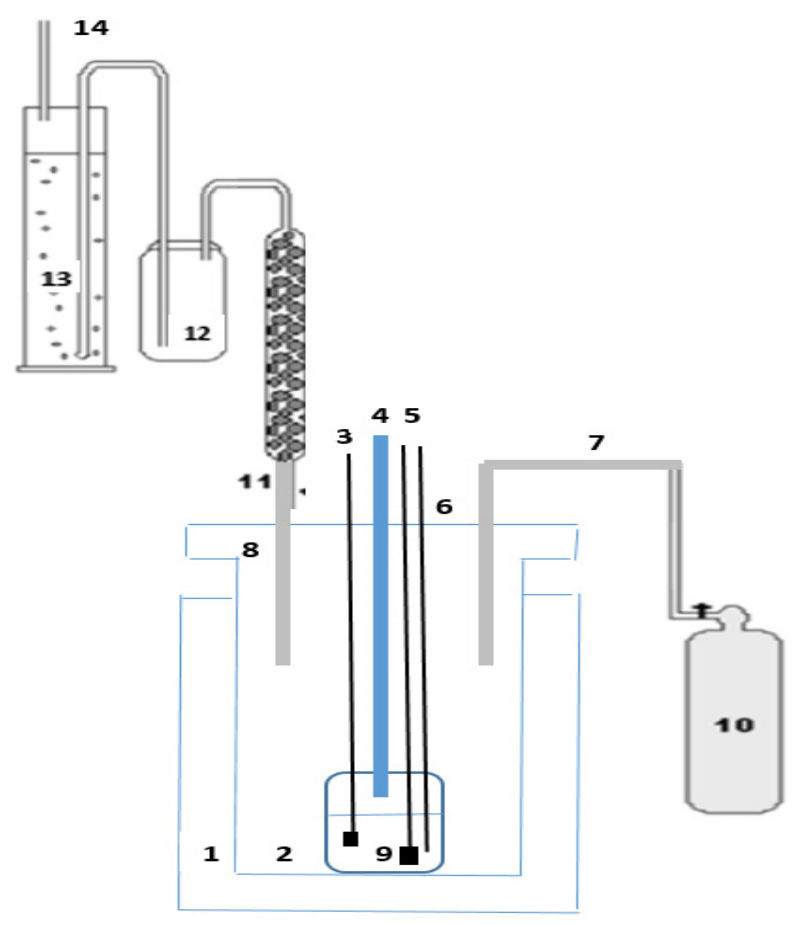

Figure 1. Experimental apparatus designed for corrosion tests in controlled atmosphere. 1: furnace, 2: molten salt reactor, 3: counter electrode, 4: thermocouple, 5: working electrode, 6: reference electrode, 7: gas inlet, 9: molten salt, 10: carrier gas, 8: off-gas system (which consisted of 11: MgO trap for chlorine, 12: moisture removal, 13: $1 \mathrm{M} \mathrm{NaOH}$ scrubber to neutralize $\mathrm{H}^{+}$, and 14: gas exhaust).

Electrochemical impedance spectroscopy tests were carried out after 1,3 , and $5 \mathrm{~h}$ of immersion to monitor the corrosion mechanism. After $8 \mathrm{~h}$ of immersion, linear polarization resistance tests were performed from a potential of -0.6 to $0.4 \mathrm{~V}$, using a scanning range of $0.005 \mathrm{~V} / \mathrm{s}(0.00244 \mathrm{~V}$ at each step). 
Thermal treatment was performed as previously reported [5], in order to reduce the corrosive impurities present in commercial chloride molten salts, especially in $\mathrm{MgCl}_{2}$, following different isothermal steps (according to the vapor-pressure curve of hydrated $\mathrm{MgCl}_{2}$ ) and dwelling times: $70^{\circ} \mathrm{C}$ (2 h) $-117{ }^{\circ} \mathrm{C}(2 \mathrm{~h})-145^{\circ} \mathrm{C}(4 \mathrm{~h})-190{ }^{\circ} \mathrm{C}(4 \mathrm{~h})-227^{\circ} \mathrm{C}(4 \mathrm{~h})-300{ }^{\circ} \mathrm{C}(4 \mathrm{~h})-450{ }^{\circ} \mathrm{C}(3 \mathrm{~h})-600{ }^{\circ} \mathrm{C}(1 \mathrm{~h})-720{ }^{\circ} \mathrm{C}$.

The chemical composition of the commercial salt used in this research are shown in Table 1.

Table 1. Chemical composition of the ternary chloride salt tested.

\begin{tabular}{ccccccc}
\hline $\mathrm{K}(\%)$ & $\mathrm{Mg}(\%)$ & $\mathrm{Na}(\%)$ & $\mathrm{Mn}(\mathrm{ppm})$ & $\mathrm{SO}_{4}(\mathrm{ppm})$ & $\mathrm{Cl}(\%)$ & $\mathrm{H}_{\mathbf{2}} \mathrm{O}(\%)$ \\
\hline 20.6 & 11.9 & 3.4 & 1.8 & 162 & 60 & 5 \\
\hline
\end{tabular}

The use of an inert atmosphere $\left(\mathrm{N}_{2}\right)$ is key to avoid a catastrophic corrosion caused by contact with the chloride molten salts. Also, it is important to highlight the formation of the alumina protective layers in the tested alloy with low oxygen content in the molten salt (Table 1).

Anodic protection tests were carried out after thermal purification in three different alloys, whose chemical composition is shown in Table 2.

Table 2. Chemical composition of the tested alloys.

\begin{tabular}{ccccccccccc}
\hline \multirow{2}{*}{ Alloy } & \multicolumn{10}{c}{ wt.\% } \\
\cline { 2 - 11 } & $\mathbf{Z r}$ & $\mathbf{M n}$ & $\mathbf{C r}$ & $\mathbf{N b}$ & $\mathbf{C u}$ & $\mathbf{T i}$ & $\mathbf{N i}$ & $\mathbf{A l}$ & $\mathbf{M o}$ & $\mathbf{F e}$ \\
\hline OC4 & - & - & 14 & 2.5 & 0.5 & - & 25 & 3.5 & 2 & Balance \\
OCT & 0.3 & - & 14 & 3 & - & 2 & 35 & 3 & - & Balance \\
OCI & - & 5 & 14 & 1 & 3 & - & 12 & 2.5 & - & Balance \\
\hline
\end{tabular}

Electrochemical techniques were used to monitor the corrosion mechanism in the tested materials. For this purpose, an electrochemical impedance test was carried out using equivalent circuits on the basis of the corrosion mechanism model of the Randles circuit [21].

Nyquist plots were used to represent the real part of the impedance on the abscissa axis and the imaginary part on the ordinate axis, both at different frequencies [22]. The obtained semicircle represented the total impedance $(Z)$ of the Randles circuit, given by Equation (1):

$$
Z=R_{S}+\frac{1}{\frac{1}{R_{c t}}+j \omega C_{d l}}
$$

where $R_{S}$ is the resistance of the solution, $R_{c t}$ is the resistance to charge transfer, $j \omega$ is the imaginary radial frequency, and $C_{d l}$ is the capacitance of the double layer.

Several authors [22-28] have proposed that equivalent circuits are appropriate to study the main corrosion processes occurring during a molten salt corrosion attack, providing different models, i.e., a localized corrosion model, a porous layer model, or a protective layer model.

After the electrochemical impedance spectroscopy (EIS) tests, a linear polarization resistance (LPR) test was carried out. In this case, it was important to quantify the polarization resistance $R_{p}$ and the corrosion current density $i_{\text {corr }}$, given by Equation (2):

$$
i_{\text {corr }}=\frac{B}{R_{p}}
$$

where $B$ is an electrochemical constant calculated theoretically according to the Equation (3):

$$
B=\frac{\beta_{\alpha} \cdot \beta_{c}}{2.3 \cdot\left(\beta_{\alpha}+\beta_{c}\right)}
$$

where $\beta_{c}$ and $\beta_{\alpha}$ are the cathodic and anodic Tafel slope, respectively. 
The corrosion rate (CR) could be estimated through the Butler-Volmer equation shown in Equation (4):

$$
C R=\frac{i_{\text {corr }} \cdot K}{\rho_{\text {alloy }} \cdot \sum\left(\frac{f_{i} \cdot n_{i}}{M W_{i}}\right)}
$$

where $K$ is a correlation constant that defines the units of $C R$ (3272 for $C R$ in mm/year), $\rho_{\text {alloy }}$ is the alloy density $\left(\mathrm{g} / \mathrm{cm}^{3}\right), f_{i}$ is the mole fraction of element $i$ in the alloy, $n_{i}$ is the number of electrons that are transferred in element $i$, and $M W_{i}$ is the atomic weight of element $i$.

\section{Results and Discussion}

Nyquist plots obtained for alloy OC4 are shown in Figure 2. The results were fitted to a protective layer model after 1 and $3 \mathrm{~h}$ of immersion; the corrosion mechanism evolved to a localized layer model after $5 \mathrm{~h}$ of immersion. An example of the fitting analysis carried out after $1 \mathrm{~h}$ of immersion is shown in Figure 3.

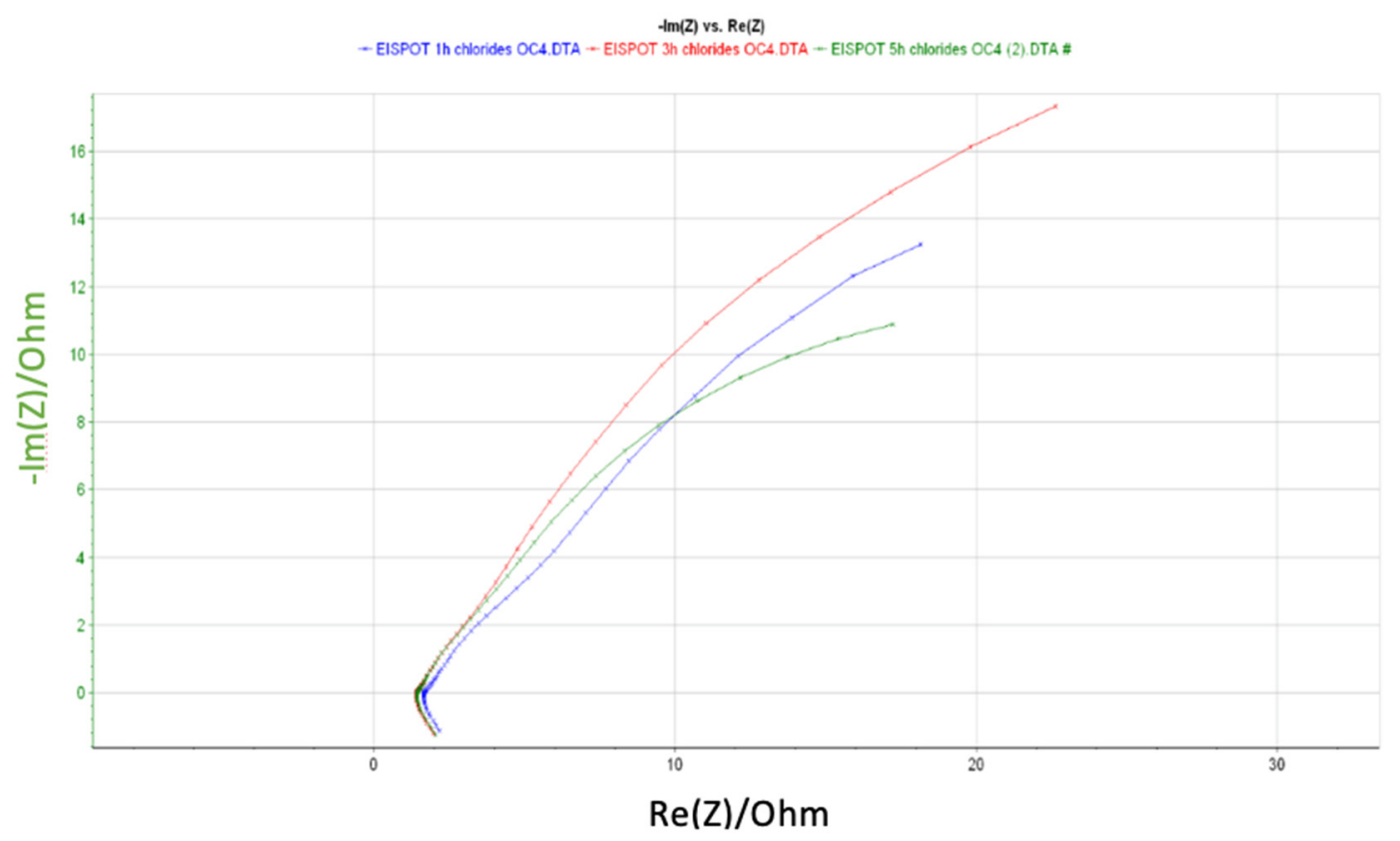

Figure 2. Nyquist diagram of alloy OC4 immersed in ternary chloride molten salt for 1, 3, and $5 \mathrm{~h}$.

Table 3. Electrochemical parameters obtained from electrochemical impedance spectroscopy (EIS) tests of OC4.

\begin{tabular}{cccccccc}
\hline Element & $\mathbf{R 3}(\mathbf{O h m})$ & $\mathbf{Q} 1(\mathrm{~F} / \mathbf{s})$ & $\mathbf{R 5}(\mathbf{O h m})$ & $\mathbf{Q} 2(\mathrm{~F} / \mathbf{s})$ & $\mathbf{R 7}(\mathbf{O h m})$ & Error (\%) & Equivalent Circuit \\
\hline $1 \mathrm{~h}$ & 1.71 & 0.66 & 26.68 & 0.17 & 7.49 & 0.52 \\
$3 \mathrm{~h}$ & 1.45 & 0.26 & 1.11 & 0.19 & 63.94 & 0.41 \\
\hline Element & $\mathrm{R} 1(\mathrm{Ohm})$ & $\mathrm{Q} 1(\mathrm{~F} / \mathrm{s})$ & $\mathrm{R} 2(\mathrm{Ohm})$ & $\mathrm{Q} 3(\mathrm{~F} / \mathrm{s})$ & $\mathrm{R} 3(\mathrm{Ohm})$ & & 0.38
\end{tabular}




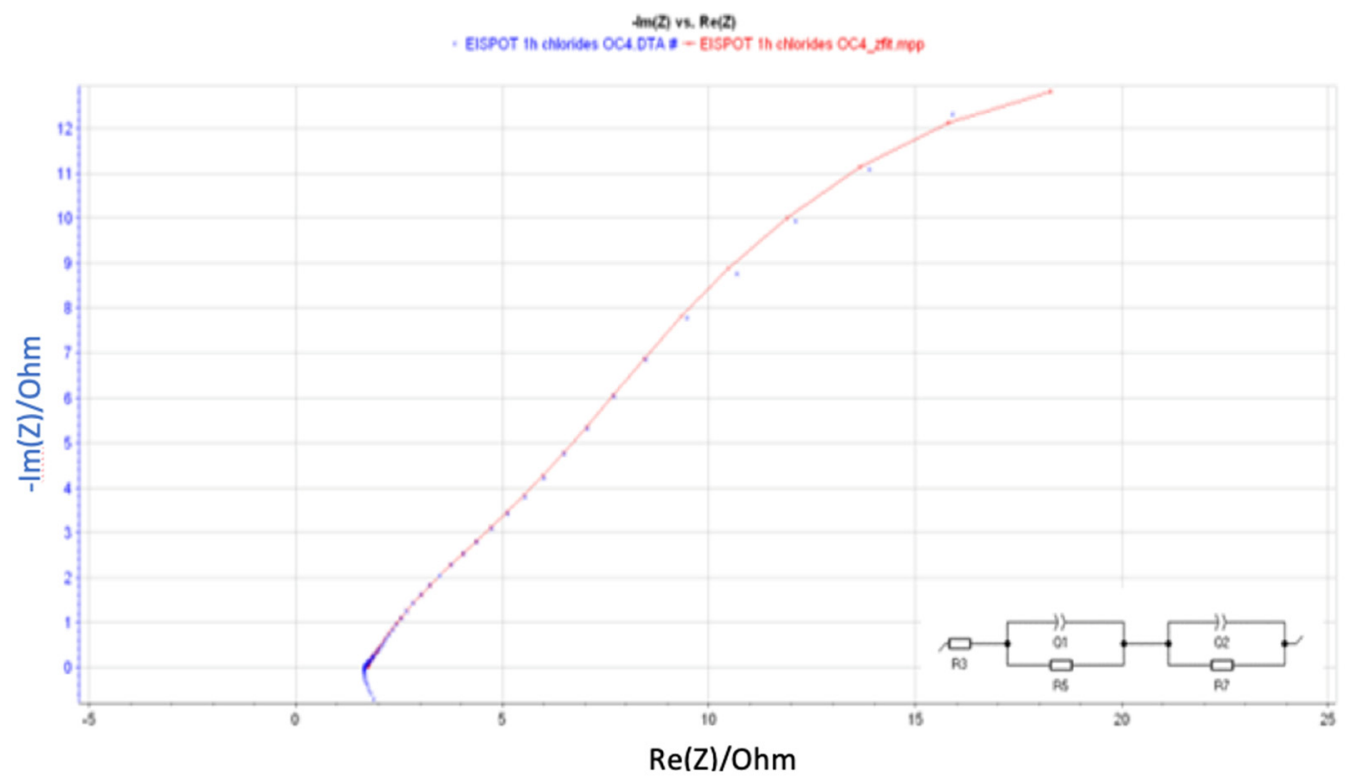

Figure 3. Nyquist diagram of OC4 immersed in ternary chloride molten salt for $1 \mathrm{~h}$ and fitting analysis to protective equivalent circuit analysis.

Equivalent circuit element values for this material are shown in Table 3. These results were confirmed by SEM analysis after the immersion test (Figure 4), indicating pitting corrosion (localized corrosion model).

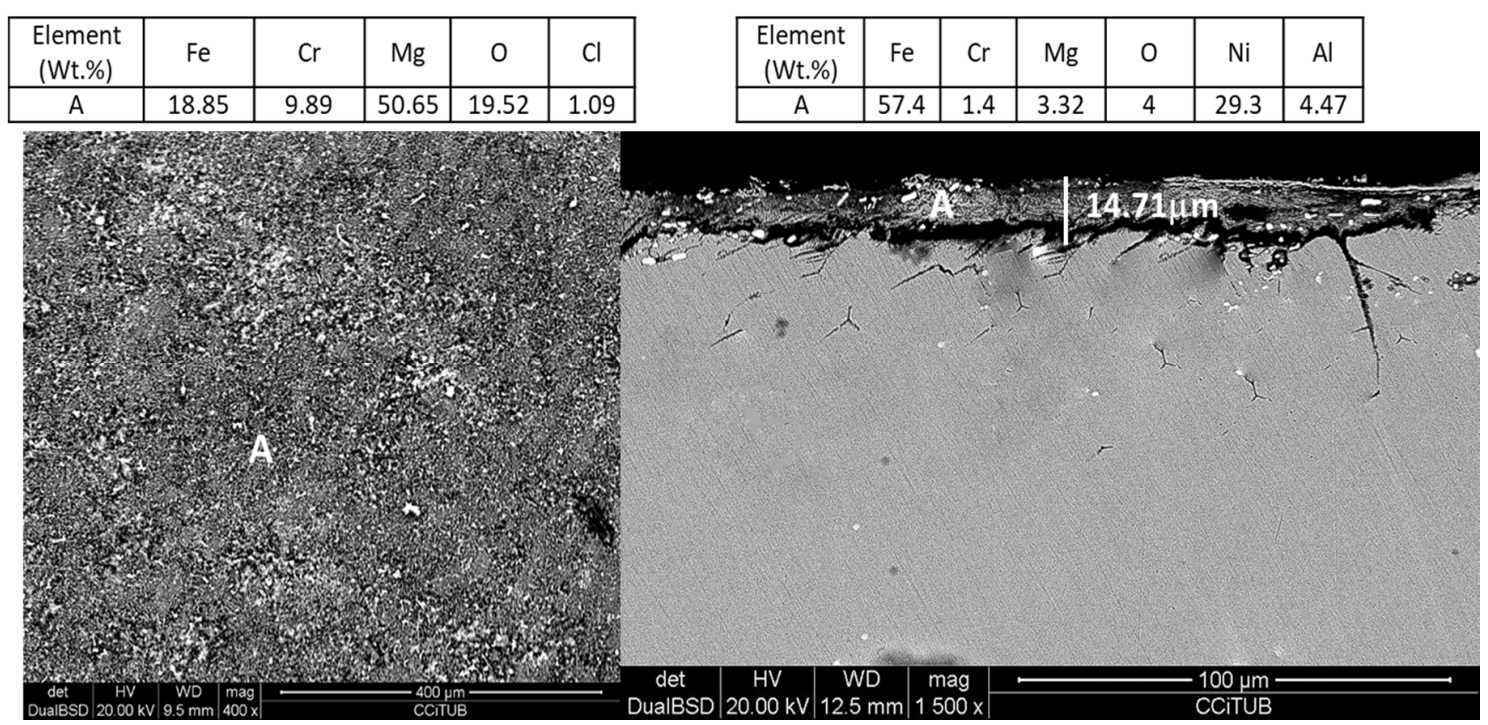

Figure 4. Micrographs showing a top view (left) and a cross section (right) of OC4 immersed in ternary chloride molten salt for $8 \mathrm{~h}$ at $720^{\circ} \mathrm{C}$; Energy dispersive X-ray (EDX) analysis on top.

The scale formed during the corrosion process seemed to be protective and contained Fe-Al-Cr-Ni-O. Nevertheless, pitting corrosion in the grain boundaries was observed at the end of the corrosion test. This effect was detected by electrochemical impedance spectroscopy and suggested a localized corrosion model.

Nyquist plots for alloy OCI are shown in Figure 5. The equivalent circuit obtained after $1 \mathrm{~h}$ (blue line) of immersion indicated a protective corrosion model; however, after 3 and $5 \mathrm{~h}$ of immersion, porous corrosion was detected. The results for the equivalent circuit elements are shown in Table 4. 
A severe corrosion process with a corrosion layer thickness of 370 microns was observed, and these results were confirmed by SEM (Figure 6).



Figure 5. Nyquist diagram of OCI immersed in ternary chloride molten salt for 1,3 , and $5 \mathrm{~h}$.

Table 4. Electrochemical parameters obtained from EIS tests of OCI alloy.

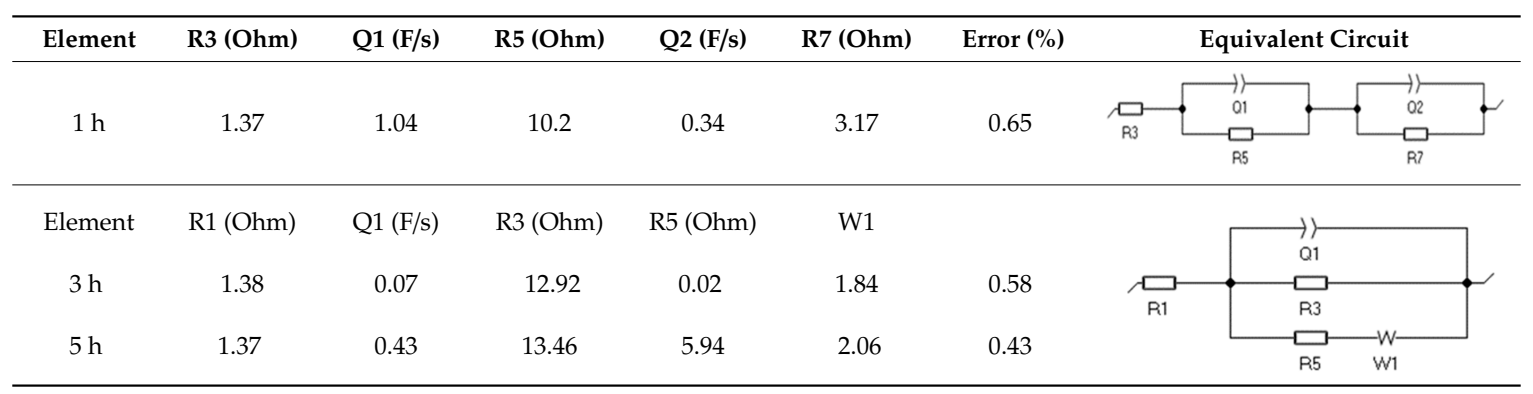



Figure 6. Micrographs showing a top view (left) and a cross section (right) of OCI immersed in ternary chloride molten salt for $8 \mathrm{~h}$ at $720^{\circ} \mathrm{C}$; EDX analysis is shown on top. 
In this case, the alloy did not generate an alumina coating on the steel surface, and the formation of a porous corrosion layer was confirmed by electrochemical and scanning electron microscopy techniques. The best results were obtained for alloy OCT, as it provided a protective corrosion model during the immersion test. Nyquist plots and equivalent circuit elements for OCT are shown in Figure 7 and Table 5. The corrosion mechanisms observed at the end of the immersion test were confirmed by SEM (Figure 8). In this case, a protective layer of $7.25 \mu \mathrm{m}$, containing Fe-Ni-Cr-O-Ti-Al, was detected.

Table 5. Electrochemical parameters obtained from EIS tests of OCT alloy.

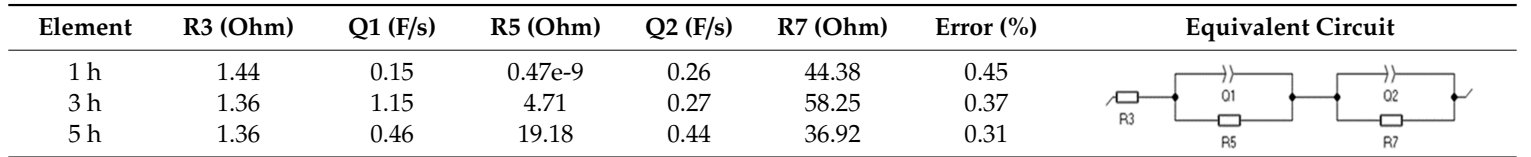

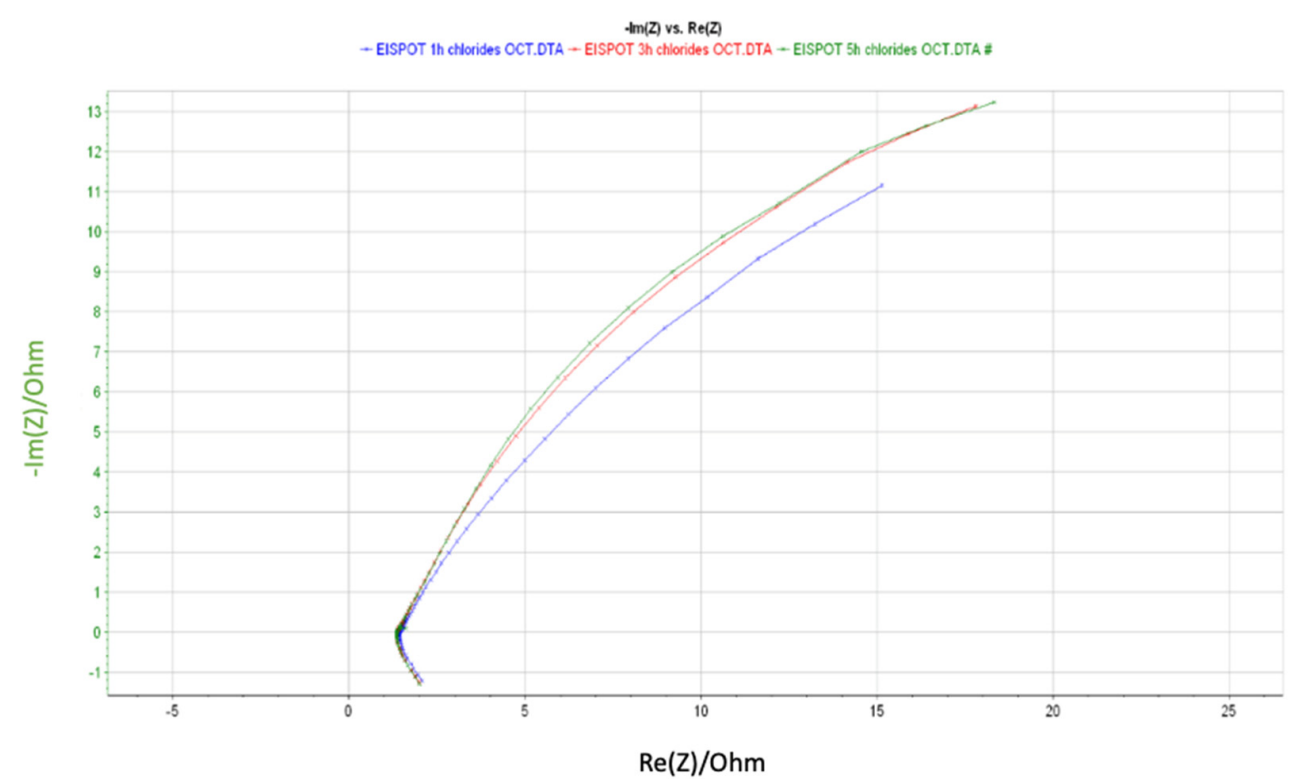

Figure 7. Nyquist diagram of OCT immersed in ternary chloride molten salt for 1,3 , and $5 \mathrm{~h}$.

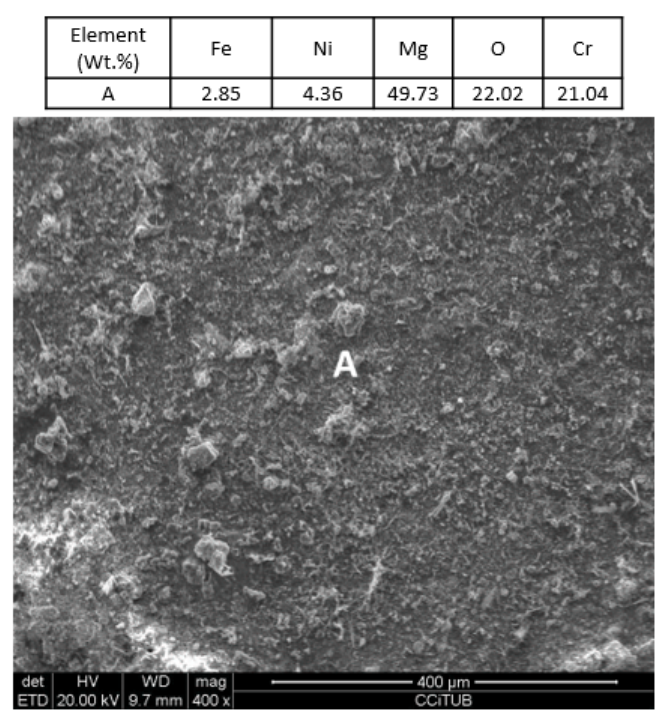

\begin{tabular}{|c|c|c|c|c|c|c|c|c|}
\hline $\begin{array}{c}\text { Element } \\
\text { (Wt.\%) }\end{array}$ & $\mathrm{Fe}$ & $\mathrm{Nb}$ & $\mathrm{Cr}$ & $\mathrm{Mg}$ & $\mathrm{O}$ & $\mathrm{Ni}$ & $\mathrm{Al}$ & $\mathrm{Ti}$ \\
\hline $\mathrm{A}$ & 41.83 & - & 13.41 & - & 2.04 & 35.41 & 1.13 & 2.37 \\
\hline B & 17.76 & 17 & - & 8.43 & 8.05 & 28.47 & 4.45 & 15.71 \\
\hline
\end{tabular}

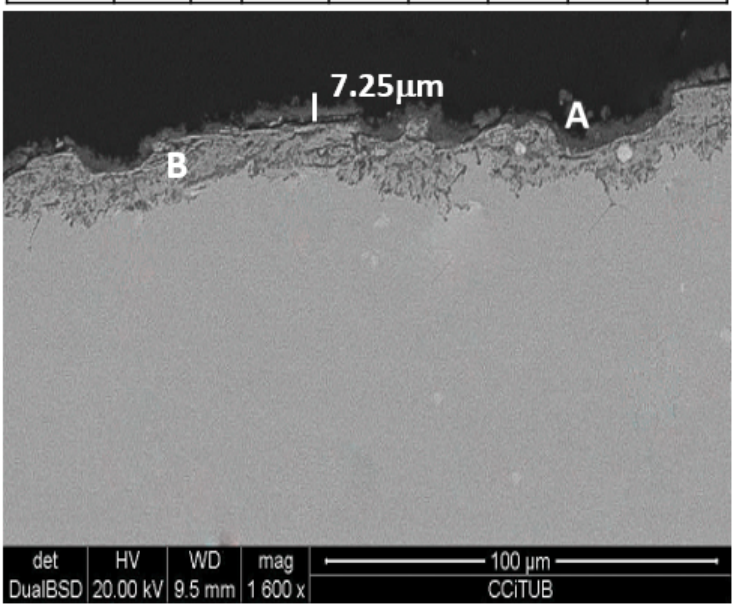

Figure 8. Micrographs showing a top view (left) and a cross section (right) of OCT immersed in ternary chloride molten salt for $8 \mathrm{~h}$ at $720^{\circ} \mathrm{C}$; EDX analysis is shown on top. 
In order to confirm the corrosion layer composition obtained on the materials' surface, an X-ray diffraction (XRD) analysis was carried out for all the materials tested (Figure 9). The chemical compounds obtained in the alloys immersed in chloride molten salts are shown in Table 6. Protective layers were obtained for OCT, confirming the better corrosion resistance obtained for this material in contact with chloride molten salt. This was confirmed by the corrosion mechanism detected using EIS.

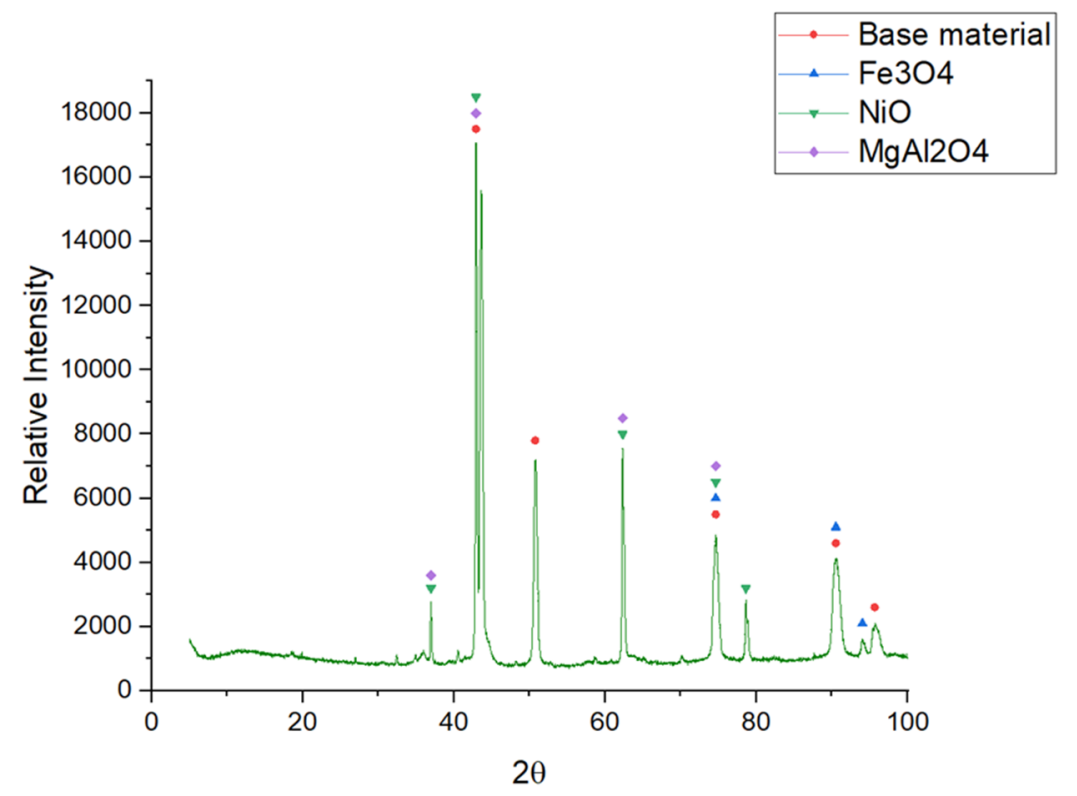

Figure 9. $\mathrm{XRD}$ analysis of OCT after $8 \mathrm{~h}$ of immersion in $20.4 \mathrm{wt} . \% \mathrm{KCl}+55.1 \mathrm{wt} . \% \mathrm{MgCl}_{2}+24.5 \mathrm{wt}$. $\%$ $\mathrm{NaCl}$ at $720^{\circ} \mathrm{C}$.

Table 6. Corrosion products identified by XRD analysis on OC4, OCI, and OCT after immersion in chloride molten salt at $720^{\circ} \mathrm{C}$ for $8 \mathrm{~h}$.

\begin{tabular}{|c|c|c|c|}
\hline Salt Mixture & Material & Corrosion Products & Reference Pattern \\
\hline \multirow{3}{*}{$\begin{array}{c}\mathrm{MgCl}_{2} / \mathrm{NaCl} / \mathrm{KCl}(55.1 \text { wt. } \%-24.5 \\
\text { wt. } \%-20.4 \text { wt. } \% \text { ) }\end{array}$} & OC4 & $\begin{array}{l}\mathrm{FeCr}_{2} \mathrm{O}_{4} \\
\mathrm{MgAl}_{2} \mathrm{O}_{4}\end{array}$ & $\begin{array}{l}00-024-0511 \\
00-033-0853\end{array}$ \\
\hline & OCI & $\begin{array}{c}\mathrm{Fe}_{2} \mathrm{O}_{3} \\
\mathrm{MgOHCl} \\
\mathrm{MgO}\end{array}$ & $\begin{array}{l}01-089-0597 \\
00-012-0120 \\
01-087-0651\end{array}$ \\
\hline & OCT & $\begin{array}{c}\mathrm{MgAl}_{2} \mathrm{O}_{4} \\
\mathrm{NiO} \\
\mathrm{Fe}_{3} \mathrm{O}_{4}\end{array}$ & $\begin{array}{l}00-033-0853 \\
03-065-6920 \\
01-086-1353\end{array}$ \\
\hline
\end{tabular}

OCI showed porous corrosion, detected by EIS, and this was confirmed by the formation of non-protective compounds such as $\mathrm{Fe}_{2} \mathrm{O}_{3}, \mathrm{MgO}$, and $\mathrm{MgOHCl}$ on the alloy's surface. These corrosion products were confirmed by XRD (Table 6). The Tafel curves obtained for the AFA alloys are shown in Figure 10. The screening test results for the materials are shown in Table 7.

The linear polarization resistance technique was applied on the materials at $720{ }^{\circ} \mathrm{C}$ after $8 \mathrm{~h}$ of immersion, obtaining a corrosion rate of $8.03,21.55$, and $7.61 \mathrm{~mm} /$ year for OC4, OCI, and OCT, respectively.

The best corrosion resistance was obtained for OCT in accordance with the EIS results (protective layer model) and the XRD/SEM results, which indicated that a protective layer consisting of $\mathrm{MgAl}_{2} \mathrm{O}_{4}$ and $\mathrm{NiO}$ formed on the surface of the steel. This internal layer formed in the OCT alloy acted as a thermal diffusion barrier, avoiding the oxidation of constitutional elements in the tested alloy. 


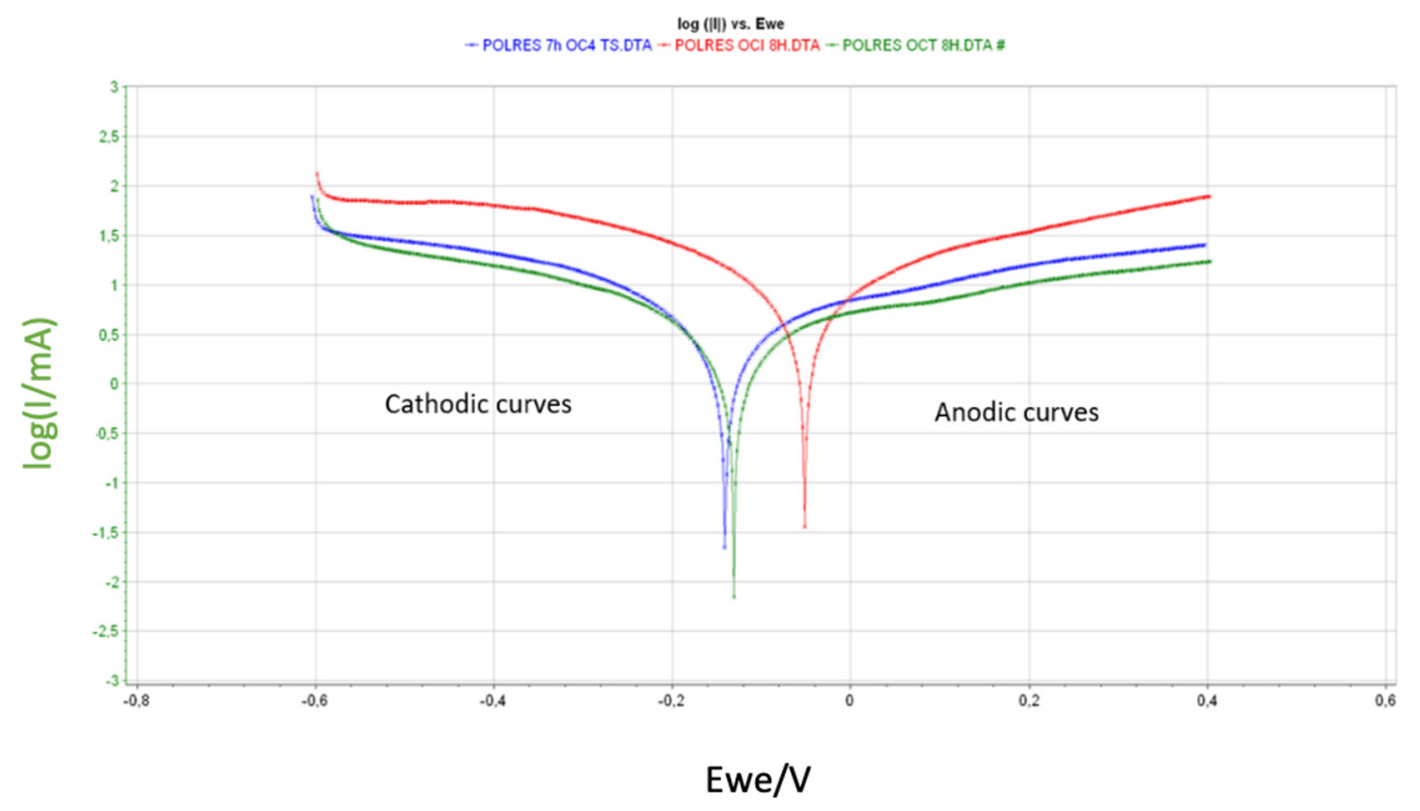

Figure 10. Tafel curves obtained from the LPR test for OCI, OC4, and OCT after $8 \mathrm{~h}$ of immersion in chloride molten salt at $720^{\circ} \mathrm{C}$.

Table 7. Electrochemical parameters and corrosion rates obtained from the linear polarization resistance (LPR) test for the tested materials.

\begin{tabular}{ccccccc}
\hline Alloys & Ecorr $(\mathbf{m V})$ & Icorr $(\mathbf{m A})$ & $\boldsymbol{\beta c} \mathbf{( m V )}$ & $\boldsymbol{\beta a} \mathbf{( m V )}$ & $\mathbf{A}\left(\mathbf{c m}^{\mathbf{2}}\right)$ & $\mathbf{C R}(\mathbf{m m} /$ year) \\
\hline OC4 & -140.79 & 4258.75 & 322.1 & 651 & 4.46 & $8.03 \pm 0.64$ \\
OCI & -52.59 & 11429.4 & 398.9 & 524.9 & 4.53 & $21.55 \pm 0.89$ \\
OCT & -131.86 & 3837.05 & 407 & 902.2 & 4.41 & $7.61 \pm 0.55$ \\
\hline
\end{tabular}

The Tafel curves, shown in Figure 10, confirmed the corrosion rates obtained in Table 7, since the following anodic current order was determined: OCI > OC4 > OCT. The anodic current order was directly related to the corrosion rate.

\section{Conclusions}

Alumina-forming alloys are a suitable option to generate protective coatings in a severe corrosion environment. In this study, AFA alloys were examined after immersion in a ternary chloride molten salt proposed as thermal energy storage (TES) material for CSP plants.

The linear polarization resistance technique was successfully applied to the tested materials, and a down selection of AFA alloys was completed. The lower corrosion rate was obtained for the OCT alloy using electrochemical impedance spectroscopy and was confirmed by SEM and XRD analyses. It is also important to highlight that, by our XRD analysis, this alloy showed internal oxidation characterized by the presence of a high amount of aluminum, which formed a protective barrier composed of $\mathrm{MgAl}_{2} \mathrm{O}_{4}$. In a future research, previously oxidized OCT alloy will be subjected to longer exposure times. The generation of alumina scales during the thermal cycles will be also analyzed, since the coating formed on the CSP plant components needs to be stable during operation.

Author Contributions: L.F.C. and A.G.F. conceived and designed the experiments; L.F.C. and A.G.F. performed the experiments and analyzed the data; A.G.F. wrote the paper. All authors contributed to the discussion and obtained results. The article was reviewed by all co-authors. All authors have read and agreed to the published version of the manuscript.

Funding: This research received no external funding. 
Acknowledgments: Angel G. Fernández would like to acknowledge the financial support from the European Union's Horizon 2020 research and innovation programme under the Marie Sklodowska-Curie grant No 712949 (TECNIOspring PLUS) and from the Agency for Business Competitiveness of the Government of Catalonia. This work was partially funded by the Ministerio de Ciencia, Innovación y Universidades de España (RTI2018-093849-B-C31 - MCIU/AEI/FEDER, UE) and the Agencia Estatal de Investigación (AEI) of the Ministerio de Ciencia, Innovación y Universidades (RED2018-102431-T). The authors would like to thank the Catalan Government for the quality accreditation given to their research group GREiA (2017 SGR 1537). GREiA is a certified agent TECNIO in the category of technology developers from the Government of Catalonia. This work is partially supported by ICREA under the ICREA Academia programme.

Conflicts of Interest: The authors declare no conflicts of interest.

\section{References}

1. Mehos, M.; Turchi, C.; Vidal, J.; Wagner, M.; Ma, Z.; Ho, C.; Kolb, W.; Andraka, C.; Kruizenga, A. Concentrating Solar Power Gen3 Demonstration Roadmap; Technical Report; NREL/TP-5500-67464; NREL: Golden, CO, USA, 2017.

2. Gomez-Vidal, J.C.; Fernandez, A.G.; Tirawat, R.; Turchi, C.; Huddleston, W. Corrosion resistance of alumina-forming alloys against molten chlorides for energy production. I: Pre-oxidation treatment and isothermal corrosion tests. Sol. Energy Mater. Sol. Cells 2017, 166, 222-233. [CrossRef]

3. Gomez-Vidal, J.C.; Fernandez, A.G.; Tirawat, R.; Turchi, C.; Huddleston, W. Corrosion resistance of alumina forming alloys against molten chlorides for energy production. II: Electrochemical impedance spectroscopy under thermal cycling conditions. Sol. Energy Mater. Sol. Cells 2017, 166, 234-245. [CrossRef]

4. Vignarooban, K.; Xu, X.; Wang, K.; Molina, E.; Li, P.; Gervasio, D.; Kannan, A.M. Vapor pressure and corrosivity of ternary metal-chloride molten-salt based heat transfer fluids for use in concentrating solar power systems. Appl. Energy 2015, 159, 206-213. [CrossRef]

5. Fernandez, A.G.; Cabeza, L.F. Corrosion evaluation of eutectic chloride molten salt for new generation of CSP plants. Part 1: Thermal treatment assessment. J. Energy Storage 2020, 27, 101125. [CrossRef]

6. Brady, M.P. The development of alumina-forming austenitic stainless steels for high-temperature structural use. JOM 2008, 60, 12-18. [CrossRef]

7. Indacochea, J.E.; Smith, J.L.; Litko, K.R.; Karell, E.J. Corrosion performance of ferrous and refractory metals in molten salts under reducing conditions. J. Mater. Res. 1999, 14, 1990-1995. [CrossRef]

8. Garcia-Diaz, B.L.; Olson, L.; Martinez-Rodriguez, M.; Fuentes, R.; Colon-Mercado, H.; Gray, J. High temperature electrochemical engineering and clean energy systems. J. South Carol. Acad. Sci. 2016, 14, 11-14.

9. Ding, W. Judith Gomez-Vidal, Alexander Bonk, Thomas Bauer, Molten chloride salts for next generation CSP plants: Electrolytical salt purification for reducing corrosive impurity level. Sol. Energy Mater. Sol. Cells 2019, 199, 8-15. [CrossRef]

10. Ding, W.; Bonk, A.; Bauer, T. Corrosion behavior of metallic alloys in molten chloride salts for thermal energy storage in concentrated solar power plants-A review. Front. Chem. Sci. Eng. 2018, 12, 564-576. [CrossRef]

11. Eom, H.-C.; Park, H.; Yoon, H.-S. Preparation of Anhydrous Magnesium Chloride from Magnesium Chloride Hexahydrate. Adv. Power Technol. 2010, 21, 125-130. [CrossRef]

12. Huang, Q.; Lu, G.; Wang, J.; Yu, J. Thermal Decomposition Mechanisms of $\mathrm{MgCl}_{2} \cdot 6 \mathrm{H}_{2} \mathrm{O}$ and $\mathrm{MgCl}_{2} \cdot \mathrm{H}_{2} \mathrm{O}$. J. Anal. Appl. Pyrolysis 2011, 91, 159-164. [CrossRef]

13. Skar, R.A. Chemical and Electrochemical Characterisation of Oxide/Hydroxide Impurities in the Electrolyte for Magnesium Production. Ph.D. Thesis, Norwegian University of Science and Technology (NTNU), Trondheim, Norway, 2001.

14. Ding, W.; Bonk, A.; Gussone, J.; Bauer, T. Electrochemical measurement of corrosive impurities in molten chlorides for thermal energy storage. J. Energy Storage 2018, 15, 408-414. [CrossRef]

15. Kashani-Nejad, S. Oxides in the Dehydration of Magnesium Chloride Hexahydrate; McGill University: Montréal, QC, CA, 2005.

16. Ding, W.; Shi, H.; Xiu, Y.; Bonk, A.; Weisenburger, A.; Jianu, A.; Bauer, T. Hot corrosion behavior of commercial alloys in thermal energy storage material of molten $\mathrm{MgCl} 2 / \mathrm{KCl} / \mathrm{NaCl}$ under inert atmosphere. Sol. Energy Mater. Sol. Cells 2018, 184, 22-30. [CrossRef]

17. Gomez-Vidal, J.C.; Noel, J.; Weber, J. Corrosion evaluation of alloys and MCrAlX coatings in molten carbonates for thermal solar applications. Sol. Energy Mater. Sol. Cells 2016, 157, 517-525. [CrossRef] 
18. Audigié, P.; Bizien, N.; Baráibar, I.; Rodríguez, S.; Pastor, A.; Hernández, M.; Agüero, A. Aluminide slurry coatings for protection of ferritic steel in molten nitrate corrosion for concentrated solar power technology. AIP Conf. Proc. 2017, 1850, 0700021-0700028.

19. Kruizenga, A.M. Corrosion Mechanisms in Chloride and Carbonate Salts; Sandia Report; SAND2012-7594; Sandia National Laboratories: Alburquerque, NM, USA, 2012.

20. Hosoya, Y.; Terai, T.; Yoneoka, T.; Tanaka, S. Compatibility of structural materials with molten chloride mixture at high temperature. J. Nucl. Mater. 1997, 248, 348-353. [CrossRef]

21. Macdonald, D. Reflections on the history of electrochemical impedance spectroscopy. Electrochim. Acta 2006, 51, 1376-1388. [CrossRef]

22. Kisza, A. The capacitance of the diffuse layer of electric double layer of electrodes in molten salts. Electrochim. Acta 2006, 51, 2315-2321. [CrossRef]

23. Orazem, M.E.; Tribollet, B. An integrated approach to electrochemical impedance spectroscopy. Electrochim. Acta 2008, 53, 7360-7366. [CrossRef]

24. Zeng, C.L.; Wang, W.; Wu, W.T. Electrochemical impedance models for molten salt corrosion. Corros. Sci. 2001, 43, 787-801. [CrossRef]

25. Fernández, A.G.; Rey, A.; Lasanta, I.; Mato, S.; Brady, M.; Perez, F.J. Corrosion of alumina-forming austenitic steel in molten nitrate salts by gravimetric analysis and impedance spectroscopy. Mater. Corros. 2014, 65, 267-275. [CrossRef]

26. Gao, G.; Stott, F.H.; Dawson, J.L.; Farrell, D.M. Electrochemical monitoring of high temperature molten salt corrosion. Oxid. Met. 1990, 33, 79-94. [CrossRef]

27. Rao, C.J.; Venkatesh, P.; Ningshen, S. Corrosion assessment of 9Cr-1Mo steel in molten $\mathrm{LiCl}-\mathrm{KCl}$ eutectic salt by electrochemical methods. J. Nucl. Mater. 2019, 514, 114-122. [CrossRef]

28. Titz, J.; Wagner, G.H.; Lorenz, W.J. In situ EIS studies of localized corrosion processes in research and industrial practice. Electrochim. Acta 1992, 37, 2309-2320. [CrossRef]

(C) 2020 by the authors. Licensee MDPI, Basel, Switzerland. This article is an open access article distributed under the terms and conditions of the Creative Commons Attribution (CC BY) license (http://creativecommons.org/licenses/by/4.0/). 